International Journal of Instruction e-ISSN: 1308-1470 • www.e-iji.net
July $2020 \bullet$ Vol.13, No.3

p-ISSN: 1694-609X

pp. 89-104

Received: 18/06/2019

Revision: 04/01/2020

Accepted: 10/01/2020

OnlineFirst:06/04/2020

\title{
Preparing for Industry 4.0 - Will youths have enough essential skills?: An Evidence from Thailand
}

\section{Wilert Puriwat}

Assoc. Prof. Dr., Chulalongkorn Business School, Chulalongkorn University, Thailand, wilert@cbs.chula.ac.th

\section{Suchart Tripopsakul}

Asst. Prof. Dr., corresponding author, School of Entrepreneurship and Management, Bangkok University, Thailand, suchart.t@bu.ac.th

In order to overcome the middle income trap and enhance Thailand's economy from efficiency driven to an innovation driven economy, Thailand currently is implementing the industry 4.0 concept - the "Thailand 4.0 " policy. Thailand 4.0 is as main tool involving the integration of new core elements such as innovation, knowledge, technology and creativity into all our core policies both economic and social. Youths can be seen as an engine for achieving this goal. However, youths' readiness in the face of the Industry 4.0 and the demands of life in the 21 st century skills still are questionable. The previous study shows that youth unemployment rate is approximately three times bigger than the adult one. This situation represents world's future workforce is not industry 4.0 ready and the next important question is to not ready in what ways. The purpose of this study is to investigate the readiness levels of Thailand's youth in adopting and leaping to the Thailand 4.0 concept. Based on 132 samples of graduate students in Thailand, the survey research was used to gather the data. Descriptive statistics and one way Anova technique were used to analyze the data. The result shows that the lowest skill set for Thailand 4.0 is the digital and information skill which can be interpreted as the poor level following by learning and innovation skill $(\mathrm{M}=3.03)$, and life and career skill.

Keywords: youths, industry 4.0, Thailand 4.0 policy, readiness, essential skills, Thailand

\section{INTRODUCTION}

In Thailand, the concept of Industry 4.0 firstly came up in 20 year national strategy (2017-2036) plan. Thailand is newly industrialized country in Southeast Asia and has expected to enhance from the stage of developing to developed country and target to increase GDP per capital from 4,121 to 15,000 dollars in the next 20 years.

Citation: Puriwat, W., \& Tripopsakul, S. (2020). Preparing for Industry 4.0 - Will youths have enough essential skills?: An Evidence from Thailand. International Journal of Instruction, 13(3), 89-104. https://doi.org/10.29333/iji.2020.1337a 
In order to overcome an economic downturn and aging society situation, the present Thai Government has announced a new national development policy, called Thailand 4.0 policy. The concept of Thailand 4.0 also currently has been proposed and emphasized with closely related to the concept of Industry 4.0. Innovation, digital economy based, high technological industries are the driven tool for Thailand in the next era. Thailand 4.0 is the vision to transform Thai economy into an innovation-driven. The Thailand 4.0 policy has been introduced with an emphasis on innovation and consists of three objectives. Firstly, Thailand becomes a high-income nation through developing it as a knowledge-based economy, with an emphasis on R\&D, science and technology, creative thinking, and innovation. Secondly, Thailand will moves toward a society with equitable access to the fruits of prosperity and development. Thirdly, Thailand will emphasis on achieving sustainable growth and development, with environment friendly mindset (Luanguepin, 2016). The concept of Thailand 4.0 classified the stages of economic development into 4 phrases (Appendix A).

Developing and emerging countries, such as Thailand, India, Pakistan, Indonesia, Brazil, Malaysia, and Nigeria have been trying to adapt to Industry 4.0 (Bahrin, Othman, Azli, \& Talib, 2016; Berawi, 2018). However, shortages of industry-ready skilled workers present one of the biggest challenges for those developing and emerging countries (Jones \& Pimdee, 2017)

Sondergaard and Lathapipat (2017) stated that there have still been the big gaps for Thailand for leaping to Industry 4.0. One of the most vital gaps for Thailand for leap to Industry4.0 is education. By one popular estimate, $65 \%$ of children entering primary school today will ultimately end up working in completely new job types that don't yet exist (World Economic Forum, 2016). The previous study has shown that different countries have different level of industry 4.0 readinesses and need customized strategies to achieve their goal (Siau, Xi, \& Zou, 2019).

Although discussions on Industry 4.0 have been ongoing for a while, only a few countries have formed clear initiatives to guide their manufacturing industries toward the fourth revolutionary wave. Most are developed countries, and a few are newly industrialized countries. Developed countries such as Germany, USA, Canada, Switzerland, Singapore, and Japan seem to most be prepared and lead ahead other newly industrialized countries such as China, India and so on. Other newly industrialized countries such as Thailand have favorable current production bases but future development is potentially challenging. Education 4.0 is a response to the requirements of industry 4.0 where human and technology are associated to facilitate novel potential. Although Education 4.0 is one of the essential mechanisms for nations to leap to Industry 4.0, the Education 4.0 strategy and implementation should be varied based on each country (Welsh, 2018). In other words, standardized strategies and roadmaps for Education 4.0 are not be able to fit all and suitable for all countries.

According to Tinmaz and Lee (2019), there is a remarkable portion of people in every country who are not aware of Industry 4.0 and its impact on their life. Especially, young generations are presently being challenged to prepare for Industry 4.0 with limited appropriate education system or particular teaching and training programs in educational 
institutions. Consequently, it is important to investigate Industry 4.0 readiness of students particular in higher education institutions or universities who will shortly be a nation's workforces and important changes are anticipated to arise as a result of Industry 4.0 revolution.

\section{REVIEW OF LITERATURE}

\section{Industry 4.0}

The concept of industry 4.0 originally came from Germany in 2011 . Industry 4.0 defines a methodology to generate a transformation from machine dominant manufacturing to digital manufacturing. The promotion of the industrial change and the acquisition of a leadership position in manufacturing sector in the world, were the main objectives of the country (Bartodziej, 2017). At the same time, USA developed the Advanced Manufactured Partnership, a re-industrialization plan, aimed at innovating manufacturing through the adoption of intelligent production systems and improving the occupational level of the country. In 2011, the United States launched the "Advanced Manufacturing Partnership" plan, in order to innovate the manufacturing system of the country, increasing productivity and reducing costs. With a greater delay, in 2015, France launched the "Alliance for the Future" program, to implement the digitization process for support innovation, and in 2016, Italy, approved the "Industry 4.0" plan (Baldassarre, Ricciardi, \& Campo, 2017).

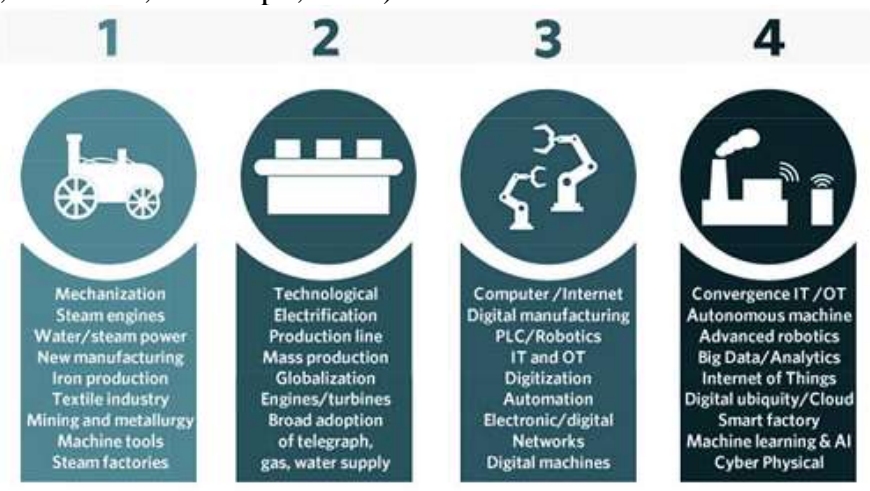

Figure 1

The Stage of Industrial Revolution. Source: Baldassarre, Ricciardi, \& Campo (2017)

According to Rojko (2017), stages in the development of industrial manufacturing systems from manual work towards Industry 4.0 concept can be presented as a path through the four industrial revolutions. The development is depicted in Figure 1.

The first industrial revolution began with the mechanization and mechanical power generation in 1800s. It brought the transition from manual work to the first manufacturing processes; mostly in textile industry. An improved quality of life was a main driver of the change. 
The second industrial revolution was triggered by electrification that enabled industrialization and mass production. Often mentioned in this context is a quote of Henry Ford, who said about the Ford T-Model car 'You can have any color as long as it is black.' The quote captures well the introduction of mass production but without the possibility of products' customization.

The third industrial revolution is characterized by the digitalization with introduction of microelectronics and automation. In manufacturing this facilitates flexible production, where a variety of products is manufactured on flexible production lines with programmable machines. Such production systems however still do not have flexibility concerning production quantity.

The fourth industrial revolution that was triggered by the development of Information and Communications Technologies (ICT). Its technological basis is smart automation of cyber physical systems with decentralized control and advanced connectivity (IoT functionalities). The consequence of this new technology for industrial production systems is reorganization of classical hierarchical automation systems to self-organizing cyber physical production system that allows flexible mass custom production and flexibility in production quantity. According to a study conducted by the American firm, the Boston Consulting Group cited in Baldassarre, Ricciardi, \& Campo (2017), the enabling technologies of Industry 4.0 are as the Table 2.

Table 2

The Enabling Technologies of Industry 4.0

\begin{tabular}{ll}
\hline Advanced Manufacturing & \multicolumn{1}{c}{ Technologies of Industry 4.0 } \\
Solutions & $\begin{array}{l}\text { Such as collaborative, autonomous and programmable robot, which are } \\
\text { able to interact each other and with people. }\end{array}$ \\
\hline Augmented Reality & $\begin{array}{l}\text { Which is a set of tools that allow you to add information to those really } \\
\text { feel. }\end{array}$ \\
\hline Additive Manufacturing & $\begin{array}{l}\text { This refers to the creating objects through additive production processes, } \\
\text { mainly through 3D printing. Through various basic technologies that differ } \\
\text { mainly due to the ability to employ different materials, additive } \\
\text { manufacturing allows companies to produce prototypes and finished } \\
\text { products directly on the market, or produce individual components that can } \\
\text { also value products in terms of design. }\end{array}$ \\
\hline Simulations & $\begin{array}{l}\text { Which are necessary to optimize products and processes, minimizing the } \\
\text { number of errors. }\end{array}$ \\
\hline Vertical and Horizontal & $\begin{array}{l}\text { Throughout the entire value chain, from supplier to end-consumer. } \\
\text { Integration of information }\end{array}$ \\
\hline Cybersecurity & $\begin{array}{l}\text { This represents the need to protect the computer systems, ensuring a } \\
\text { network security. }\end{array}$ \\
\hline Big Data & $\begin{array}{l}\text { Which represents the collection and analysis of large amounts of data to } \\
\text { improve products and production processes }\end{array}$ \\
\hline The Cloud & $\begin{array}{l}\text { Which represent the need to share large amounts of data or IT resources, } \\
\text { available by the Internet and accessible at all times. }\end{array}$ \\
\hline The Industrial Internet of & $\begin{array}{l}\text { Which represents the set of technologies and sensors that enable } \\
\text { communication between artificial world and people, including products and } \\
\text { production processes }\end{array}$ \\
\hline Shings &
\end{tabular}

Source: Boston Consulting Group (2015) cited in Baldassarre, Ricciardi, \& Campo (2017) 


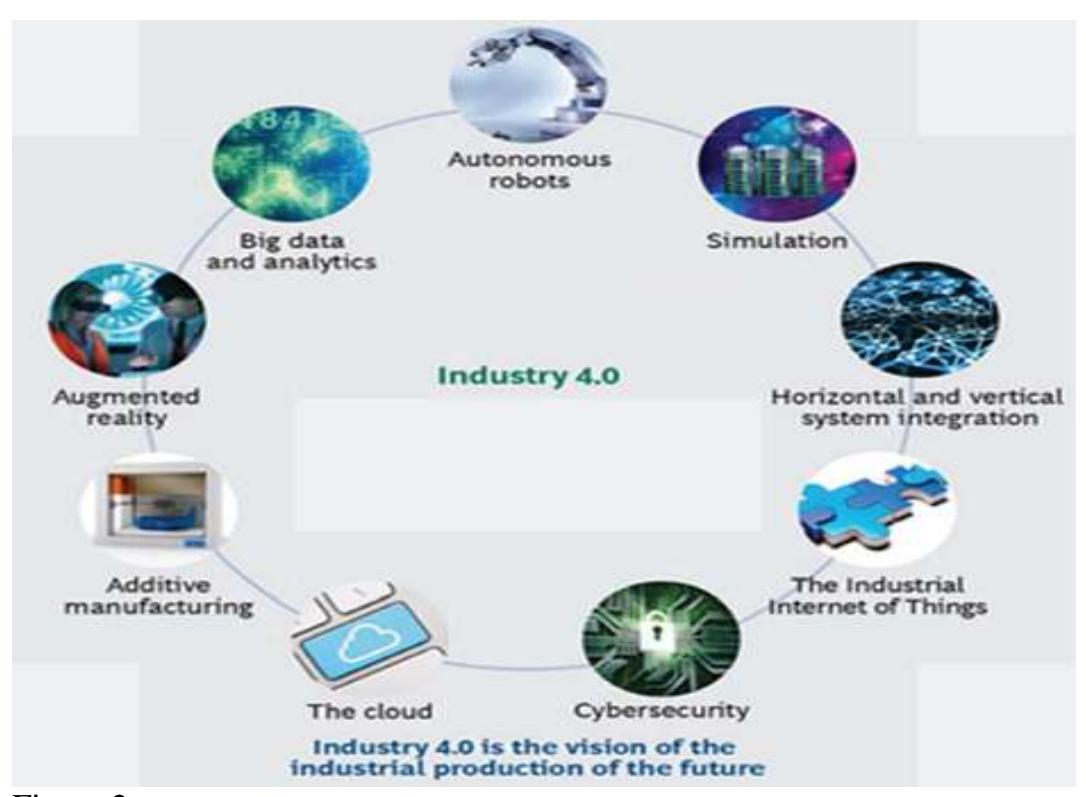

Figure 2

Nine Technologies for Industry 4.0. Source: Boston Consulting Group (2015) cited in Baldassarre, Ricciardi, \& Campo (2017)

\section{The Fourth Industrial Revolution (4IR) and Thailand 4.0}

Thailand 4.0 is the vision to transform Thai economy into an innovation-driven economic. The new approach to "work a little but make big gains" rather than "working hard for just a little gain". In order to achieve this approach, Thai economy must transform itself from being industry-driven to the innovation-driven or technologydriven. The concept of Thailand 4.0 is to explore the usage of science, technology and innovation to boost the country's economy, focusing on industrial and agricultural sectors, medical technology and public health, together with the global trend for a robotics industry (Wipatayotin, 2017). Further challenges however will be overcoming "a middle- income trap", "an inequality trap", and "an imbalanced trap" (Thai EmbassyWashington, D.C., 2017).

In order to overcome three traps, Thailand will use the new growth engines; namely, (1) Building economic prosperity through innovation, knowledge, technology, and creativity. This creates a "competitive growth engine" to unlock individuals from the middle-income trap. (2) Building social security through equitable distribution of income, opportunity, and wealth, operating under a principle of "moving forward together without leaving anyone behind" to unlock Thai citizens from the inequality trap. (3) Creating sustainability through environmentally friendly development (Green Growth Engine), to unlock Thai citizens from an imbalance trap (Jones, \& Pimdee, 2017). 
The Thailand 4.0 development plan is focused on 10 targeted industries divided into two broad categories: (1) First 5 S-Curve industries (existing industries): Next-Generation Automotive, Intelligent Electronics, Advance Agriculture and Biotechnology, Food Processing and Tourism aims to enhance the competitiveness of the country current strengths through technology innovation. (2) 5 New S-Curve industries (new industries): Digital, Robotics and Automation, Aviation and Logistics, Biofuels and Biochemicals and Medical Hub aims to develop five additional industries to accelerate on the new industrial base growth (Thailand Investment Review, 2017; Tantivorawong, 2015).

Table 3

Thailand 4.0 Future Industry Development Targets

\begin{tabular}{ll}
\hline \multicolumn{2}{l}{ Thailand 4.0 new S-curve industries } \\
\hline Robotics & $\begin{array}{l}\text { Robots for the automotive, plastics, medical, \& electronic industries. Robots } \\
\text { for underwater support (Remotely Operated Underwater Vehicles-ROVs) }\end{array}$ \\
\hline $\begin{array}{l}\text { Aviation \& } \\
\text { Logistics }\end{array}$ & $\begin{array}{l}\text { Transport services - Modern logistics service centers - Aviation } \\
\text { maintenance, repair, \& overhaul (MRO) - Manufacture of aviation parts } \\
\text { (OEM) - High Value Business with time sensitive products - Aviation } \\
\text { Training Centers }\end{array}$ \\
\hline Medical Hub & $\begin{array}{l}\text { Telemedicine - Consulting, diagnosis, \& testament - Remote } \\
\text { health monitoring device manufacturing - Biologics \& Biosimilars }\end{array}$ \\
\hline Biofuels \& & $\begin{array}{l}2^{\text {nd }} \text { generation biofuels - Development of the biochemical industry } \\
\text { Bio chemicals }\end{array}$ \\
\hline midstream sector - bioplastics - Bio Economy \\
\hline & $\begin{array}{l}\text { Embedded software, enterprise software and digital content - E-commerce } \\
\text { (sell - buy - pay - deliver), Consumer data mining and data centers - cloud }\end{array}$ \\
& $\begin{array}{l}\text { computing - cyber security - Internet of Things: Enabled smart city - } \\
\text { creative media and animation }\end{array}$
\end{tabular}

Source: Jones, \& Pimdee (2017)

According to the Thai Embassy web site in Washington, D.C., the four stated objectives of Thailand 4.0 are as follows: (1) Economic Prosperity: to create a value-based economy that is driven by innovation, technology and creativity. The model aims to increase Research and Development ("R\&D") expenditure to 4\% of GDP, increase economic growth rate to full capacity rate of 5-6\% within 5 years, and increase national income per capita from 5,470 USD in 2014 to 15,000 USD by 2032. (2) Social Wellbeing: to create a society that moves forward without leaving anyone behind (inclusive society) through realization of the full potential of all members of society. The goals are to reduce social disparity from 0.465 in 2013 to 0.36 in 2032, completely transform to social welfare system within 20 years and develop at least 20,000 households into "Smart Farmers" within 5 years. (3) Raising Human Values: to transform Thais into "Competent human beings in the 21 sth Century" and "Thais 4.0 in the first world. Measures under Thailand 4.0 will raise Thailand HDI from 0.722 to 0.8 or the top 50 countries within 10 years, ensure that at least 5 Thai universities are ranked amongst the world's top 100 higher education institution within 20 years. (4) Environmental Protection: to become a livable society that possesses an economic system capable of adjusting to climate change and low carbon society. The targets are to develop at least 10 cities into the world's most livable cities, reduce terrorism risk, and increase the proportion. 


\section{Education 4.0}

The background of education 4.0 is from the period of 1.0-3.0 economy development. Education 1.0 had the main purpose to produce human resource in order to serve the agricultural economy and traditional agrarian society (Green evaluation) (University of Phayao). Education 2.0 was a revolution education that had focused to produce graduates for working in industry especially light industry, hence to operate the light industry, the nation had imported substitution and used more natural resources and had a cheap labor cost and developed the nation by using new technology. Education 3.0, it had continual developed the approach of technology used became used global network, internet technology to share and earn knowledge for improving the learning skills (knowledge education)in order to serve the demand of skillful human resource of heavy industry business and foreign direct investment. Education 4.0 has transformed globalization to the innovation's education, the main purpose of this education era is to produce graduates which much higher skills on innovation and digital technology than before. It weighs on the creative and innovative thinking skills to drive and cross over the poverty of nation for becoming the prosperity and sustainability of economy and society. According to Bamrungsin (2017), the essential skills of Thailand 4.0 and the $21^{\text {st }}$ century can be gathered into 3 groups and can be offered the meaning of each skill as follows.

Table 4

The Essential Skills of Thailand 4.0

\begin{tabular}{|c|c|c|}
\hline Main skill & Sub skill & Definition \\
\hline \multirow[t]{3}{*}{$\begin{array}{l}\text { Innovation } \\
\text { skills }\end{array}$} & $\begin{array}{l}\text { Innovative } \\
\text { thinking }\end{array}$ & $\begin{array}{l}\text { The skills to judge, consider or contemplate in order to produce, create the } \\
\text { featuring new methods; advanced and original (English oxford living } \\
\text { dictionary, 2017) such as produce new media design, application and } \\
\text { evaluation for learning and working. }\end{array}$ \\
\hline & $\begin{array}{l}\text { Creative } \\
\text { thinking }\end{array}$ & $\begin{array}{l}\text { Emphasizes the skills of generative or divergent in positive way, the ability } \\
\text { to imagine or invent something new in order to improve the learning, } \\
\text { working, profession and so on. }\end{array}$ \\
\hline & $\begin{array}{l}\text { Critical } \\
\text { thinking and } \\
\text { problem solving }\end{array}$ & $\begin{array}{l}\text { Self-guided, self-disciplined thinking which attempts to reason at the } \\
\text { highest level of quality in a fair-minded way. People who think critically } \\
\text { consistently attempt to live rationally, reasonably, empathically etc. They } \\
\text { are keenly aware of the inherently flawed nature of human thinking when } \\
\text { left unchecked (The critical thinking community, 2017). Hence, the critical } \\
\text { thinking in the same way of Buddhist context also refers to the cognitive } \\
\text { and wisdom skills that one can be able to analyze the cause of problems, } \\
\text { looking for the suitable ways to solve the problems, has an initiative skill to } \\
\text { fine the available approach for preventing the problem in the various and } \\
\text { suitable context of culture, society, background and field of study. }\end{array}$ \\
\hline \multirow[t]{3}{*}{$\begin{array}{l}\text { Digital and } \\
\text { information } \\
\text { skills }\end{array}$} & Digital literacy & $\begin{array}{l}\text { The skill to selecting sources of information for research using digital } \\
\text { technology in information retrieval; collecting and evaluating information } \\
\text { qualities; analyzing and synthesizing information; writing reports and } \\
\text { referencing; security, effects, ethics, morals, and laws regarding media and } \\
\text { digital technology using. }\end{array}$ \\
\hline & ICT literacy & $\begin{array}{l}\text { The perception of principles and importance of IT system and information } \\
\text { system in researching; usage of IT and other media in research and } \\
\text { electronic database in order to develop communication and online learning, } \\
\text { researching, writing reports of one's research and ethics of IT usage. }\end{array}$ \\
\hline & Media literacy & Understand the different types of suitable method for learning to teaching, \\
\hline
\end{tabular}

International Journal of Instruction, July $2020 \bullet$ Vol.13, No.3 


\begin{tabular}{|c|c|c|}
\hline & & $\begin{array}{l}\text { production and selection to use media for learning, application of } \\
\text { Information Technology for learning-teaching, the various kinds of } \\
\text { instructional method and different types of natural media and wisdom } \\
\text { media for learning-teaching, the effective instructional media for } \\
\text { development of the system of Information Technology, internet and } \\
\text { computer to help teach in professional area. }\end{array}$ \\
\hline \multirow[t]{4}{*}{$\begin{array}{l}\text { Life and } \\
\text { career skills }\end{array}$} & $\begin{array}{l}\text { Adaptability, } \\
\text { flexibility and } \\
\text { collaborative } \\
\text { skills }\end{array}$ & $\begin{array}{l}\text { The abilities to live and adjust property and timely Thailand } 4.0 \text { and the } 21^{\text {st }} \\
\text { century' society, social interaction especially ASEAN and global interaction } \\
\text { for the learning or working's achievement. In addition the collaborative } \\
\text { skills is very crucial in this current situation, this means the ability to work } \\
\text { with others, collaborate with many people who may have different } \\
\text { backgrounds, ideas, beliefs, or knowledge in order to attain the } \\
\text { achievement. }\end{array}$ \\
\hline & $\begin{array}{l}\text { Self-direction } \\
\text { for the desirable } \\
\text { value skills }\end{array}$ & $\begin{array}{l}\text { Personal ethics and professional ethics such as self - discipline, love and } \\
\text { have faith in their profession, discharge their responsibilities with integrity }\end{array}$ \\
\hline & $\begin{array}{l}\text { Civic and } \\
\text { global citizen }\end{array}$ & $\begin{array}{l}\text { An awareness of ethics, good governance and responsibility on social } \\
\text { conscience especially one's role and duties as a good civic and global } \\
\text { citizen. Understand a holistic application of ethics in society, preventing } \\
\text { and solving problems of corruption and building social well-being } \\
\text { according to ethical teachings. In addition, understand the important } \\
\text { concepts of international relations; international organizations; } \\
\text { transboundary impacts of global phenomena }\end{array}$ \\
\hline & English skills & $\begin{array}{l}\text { Usage of } 4 \text { English skills which are listening, speaking, reading and writing } \\
\text { for learning and working in daily life such as giving information, making } \\
\text { summary and expressing opinions; strategies of listening, speaking, reading } \\
\text { and writing in daily life; citations and usage of dictionary for reading and } \\
\text { writing based on Information system and electronic databases. }\end{array}$ \\
\hline
\end{tabular}

The purpose of this study is to investigate the readiness of youth for Thailand 4.0. Since human capital seems to be one of the vital key success factors in order to achieve the concept of Thailand 4.0, this study objective is to represent the current situation of understanding of Thailand 4.0 and Industry 4.0. Industry 4.0 requires not only just workforce, but also human capital nurtured in competitive education systems that is well prepared for creative work environments. Therefore, as humans embrace to usher in Industry 4.0, it has become imperative for nations as well as organizations to embark on education systems that are more focused on knowledge beyond what the world currently preach. This may require teaching creativity to children at an early age right up to university levels. A move away from traditional education systems of writing, reading, cramming and memorizing as mode of passing an examination that never produce thinkers, creators and ingenuity should be a thing of the past. Therefore, nations need to revolutionize their education systems that produce super humans capable of surviving in Industry 4.0 revolution. Education revolutions require a national culture that is supportive to such initiatives from government, where the citizens feel they have something to contribute towards achieving Industry 4.0 revolution goals (Agolla, 2018).

\section{METHOD}

The author adopted the concept of the essential skills of Thailand 4.0 and the $21^{\text {st }}$ century by The Office of the Higher Education Commission (OHEC), Ministry of 
Education, and Thailand. According to Bamrungsin (2017), the necessary skills for Thailand 4.0 can be classified into 3 main groups. The empirical survey research is used for this study. A questionnaire instrument is developed to investigate the level of readiness of essential skills for Thailand 4.0. Based on previous works of Bamrungsin (2017) and Hartmann \& Bovenschulte (2013), the author adopted and modified questionnaire items to assess a readiness level of those 3 groups of skills; namely, learning and innovation (LIS), digital and information (DIS), and life and career skill set (LCS). 3 items were used to find out the average of LIS, 10 items for DIS, and 4 items for LCS. Participants were asked to use a self-assessment approach to evaluate his or her level of understanding and readiness in those 3 groups of skills. The research items are summarized as the Table 5 .

Table 5

The Thailand 4.0 Essential Skill Dimensions and Items

\begin{tabular}{|c|c|}
\hline Dimensions & Question \\
\hline $\begin{array}{l}\text { Thailand } \\
4.0 \text { literacy }\end{array}$ & How would you describe your ability to define/implement Industry 4.0 strategy? \\
\hline \multirow{9}{*}{$\begin{array}{l}\text { Digital and } \\
\text { information } \\
\text { skill (DIS) }\end{array}$} & $\begin{array}{l}\text { What is the level of your understanding of IT Knowledge and technology with } \\
\text { respect to Industry 4.0? (DIS2 ) }\end{array}$ \\
\hline & $\begin{array}{l}\text { What is the level of your understanding of Computer programming/coding abilities } \\
\text { with respect to Industry } 4.0 \text { (DIS3) }\end{array}$ \\
\hline & $\begin{array}{l}\text { What is the level of your understanding of Data and information processing and } \\
\text { analytics with respect to Industry 4.0 (DIS4) }\end{array}$ \\
\hline & $\begin{array}{l}\text { What is the level of your understanding of Data Analytic/Statistical knowledge } \\
\text { with respect to Industry } 4.0 \text { (DIS5) }\end{array}$ \\
\hline & $\begin{array}{l}\text { What is the level of your understanding of IT security and data protection with } \\
\text { respect to Industry } 4.0 \text { (DIS6) }\end{array}$ \\
\hline & $\begin{array}{l}\text { What is the level of your understanding of Smart Work \& Ergonomics with respect } \\
\text { to Industry } 4.0 \text { (DIS7) }\end{array}$ \\
\hline & $\begin{array}{l}\text { What is the level of your understanding of Smart Product with respect to Industry } \\
4.0 \text { (DIS8) }\end{array}$ \\
\hline & $\begin{array}{l}\text { What is the level of your understanding of Co-created Design with respect to } \\
\text { Industry 4.0 (DIS9) }\end{array}$ \\
\hline & $\begin{array}{l}\text { What is the level of your understanding of Smart Digital Factory with respect to } \\
\text { Industry } 4.0 \text { (DIS10) }\end{array}$ \\
\hline \multirow{3}{*}{$\begin{array}{l}\text { Learning } \\
\text { and } \\
\text { innovation } \\
\text { skill (LIS) }\end{array}$} & What is the level of innovative thinking skill with respect to Industry 4.0 (LIS1) \\
\hline & What is the level of creative thinking skill with respect to Industry 4.0 (LIS2) \\
\hline & $\begin{array}{l}\text { What is the level of critical thinking and problem solving skill with respect to } \\
\text { Industry } 4.0 \text { (LIS3) }\end{array}$ \\
\hline \multirow{4}{*}{$\begin{array}{l}\text { Life and } \\
\text { career skill } \\
\text { (LCS) }\end{array}$} & $\begin{array}{l}\text { What is the level of adaptability, flexibility and collaboration skills with respect to } \\
\text { Industry } 4.0 \text { (LCS1) }\end{array}$ \\
\hline & What is the level of social skill with respect to Industry 4.0 (LCS2) \\
\hline & $\begin{array}{l}\text { What is the level of self and time management skill with respect to Industry } 4.0 \\
\text { (LCS3) }\end{array}$ \\
\hline & What is the level of English skill with respect to Industry 4.0 (LCS4) \\
\hline
\end{tabular}




\section{FINDINGS}

Overall, 132 samples was collected by an online questionnaire. The summaries of descriptive statistics are shown in the Table 6.

Table 6

Sample Profiles of This Study

\begin{tabular}{|c|c|c|c|}
\hline & & $\mathrm{N}$ & $\%$ \\
\hline \multirow[t]{2}{*}{ Gender } & Males & 43 & 32.6 \\
\hline & Females & 89 & 67.4 \\
\hline \multirow[t]{7}{*}{ Ages } & Below 20 & 0 & 0 \\
\hline & $20-25$ & 12 & 9.1 \\
\hline & $26-30$ & 82 & 62.1 \\
\hline & $31-35$ & 29 & 22.0 \\
\hline & $36-40$ & 6 & 4.5 \\
\hline & $41-45$ & 2 & 1.5 \\
\hline & Above 45 & 1 & 0.8 \\
\hline \multirow[t]{6}{*}{ Occupation } & Business owner & 10 & 7.6 \\
\hline & Specialist (e.g. doctor, architecture, and lawyer) & 10 & 7.6 \\
\hline & Freelance & 0 & 0 \\
\hline & Full time employee & 92 & 69.7 \\
\hline & Government officer & 19 & 14.4 \\
\hline & Full time student & 1 & 0.8 \\
\hline \multirow[t]{7}{*}{ Working experience } & None & 0 & 0 \\
\hline & $1-2$ years & 4 & 3.0 \\
\hline & $3-4$ years & 30 & 22.7 \\
\hline & $5-7$ years & 59 & 44.7 \\
\hline & $8-10$ years & 25 & 18.9 \\
\hline & $11-15$ years & 9 & 6.8 \\
\hline & More than 15 years & 5 & 3.8 \\
\hline \multirow[t]{9}{*}{ Monthly income } & None & 0 & 0 \\
\hline & Less than 15,000 Baht & 0 & 0 \\
\hline & $15,001-20,000$ Baht & 12 & 9.1 \\
\hline & $20,001-30,000$ Baht & 28 & 21.2 \\
\hline & $30,001-50,000$ Baht & 45 & 34.1 \\
\hline & $50,001-75,000$ Baht & 32 & 24.2 \\
\hline & $75,001-100,000$ Baht & 5 & 3.8 \\
\hline & 100,001 - 150,000 Baht & 5 & 3.8 \\
\hline & More than 150,000 Baht & 5 & 3.8 \\
\hline \multirow{3}{*}{$\begin{array}{c}\text { Education } \\
\text { Background }\end{array}$} & Science field (e.g. Engineering, and Medicine) & 69 & 52.3 \\
\hline & Business and administration & 39 & 29.5 \\
\hline & Social science (e.g. Law, and Communication Arts) & 24 & 18.2 \\
\hline \multirow[t]{5}{*}{ Domicile } & Bangkok and greater & 78 & 59.1 \\
\hline & Central & 25 & 18.9 \\
\hline & Northeast & 10 & 7.6 \\
\hline & North & 10 & 7.6 \\
\hline & South & 9 & 7.6 \\
\hline
\end{tabular}

International Journal of Instruction, July $2020 \bullet$ Vol.13, No.3 
The results are reported by using one sample $t$ test to represent the values of mean (M) and standard deviation (S.D.) details are as follows

Table 7

The Analysis Results of Samples

\begin{tabular}{lllll}
\hline & & Mean & S.D. & Interpretation \\
\hline 1 & Learning and innovation skill (LIS) & 3.03 & 0.773 & Fair \\
\hline & 1.1 Innovative thinking & 2.91 & 0.992 & Fair \\
\cline { 2 - 5 } & 1.2 Creative thinking & 3.16 & 0.931 & Fair \\
\cline { 2 - 5 } & 1.3 Critical thinking and problem solving & 3.03 & 0.873 & Fair \\
\hline 2 & Digital and information skill (DIS) & 2.59 & 0.819 & Poor \\
\hline 3 & Life and career skill (LCS) & 3.66 & 0.590 & Good \\
\hline \multirow{2}{*}{3.1 Adaptability, flexibility and collaborative skills } & 3.89 & 0.816 & Good \\
\cline { 2 - 5 } & 3.2 Self-direction for the desirable value skills & 3.83 & 0.793 & Good \\
\cline { 2 - 5 } & 3.3 Civic and global citizen & 3.67 & 0.796 & Good \\
\cline { 2 - 5 } & 3.4 English skills & 3.23 & 0.872 & Fair \\
\hline \multirow{2}{*}{4} & Industry 4.0 literacy & 3.10 & 0.828 & Fair \\
\hline
\end{tabular}

Note: The interpretation of Likert scale: $1.00-1.80=$ Very poor; $1.81-2.60=$ Poor; 2.61 3.40 = Fair; 3.41-4.20 = Good; 4.21-5.00 = Excellent

According to the table 7, Digital and information skill of samples are lowest comparing with the other skills, and digital and information skill can be interpreted "poor" from the average $(\mathrm{M}=2.59$, S.D. $=0.819)$.

In order to test the hypotheses H2, One-Way Anova technique was used to the level of learning and innovation, digital and information, and life and career skills in different demographic variables. Authors initially calculated and created the overall of learning and innovation, digital and information, and life and career skill. 3 items were used to find out the average of LIS, 10 items for DIS, and 4 items for LCS. The result of OneWay Anova analysis can be summarized in the Table 8. 
Table 8

One-Way Anova and Hypothesis Testing Results

\begin{tabular}{|c|c|c|c|}
\hline & & Sig. & Results \\
\hline $\mathrm{H} 2 \mathrm{a}$ & The level of LIS is significantly difference between males and females. & 0.348 & Not supported \\
\hline $\mathrm{H} 2 \mathrm{~b}$ & The level of LIS is significantly difference among ages. & 0.031 & Supported \\
\hline $\mathrm{H} 2 \mathrm{c}$ & The level of LIS is significantly difference among occupations. & 0.795 & Not supported \\
\hline $\mathrm{H} 2 \mathrm{~d}$ & The level of LIS is significantly difference among working experiences. & 0.029 & Supported \\
\hline $\mathrm{H} 2 \mathrm{e}$ & The level of LIS is significantly difference among level of income. & 0.407 & Not supported \\
\hline $\mathrm{H} 2 \mathrm{f}$ & nificantly difference among education backgrounds. & 0.210 & Not supported \\
\hline $\mathrm{H} 2 \mathrm{~g}$ & $\begin{array}{l}\text { The level of LIS is significantly difference among different students' region } \\
\text { of domicile }\end{array}$ & 0.825 & Not supported \\
\hline $\mathrm{H} 2$ & The level of LIS significantly differs among different demographic groups. & - & rted \\
\hline H3a & The level of DIS is significantly difference between males and females. & 0.033 & Supported \\
\hline $\mathrm{H} 3 \mathrm{~b}$ & significantly difference among ages. & 0.426 & Not supported \\
\hline $\mathrm{H} 3 \mathrm{c}$ & The level of DIS is significantly difference among occupations. & 0.845 & Not supported \\
\hline $\mathrm{H} 3 \mathrm{~d}$ & The level of DIS is significantly difference among working experiences. & 0.696 & Not supported \\
\hline $\mathrm{H} 3 \mathrm{e}$ & The le & 0.756 & upported \\
\hline H3f & The level of DIS & 0.005 & Supported \\
\hline H3g & $\begin{array}{l}\text { The level of DIS is significantly difference among different students' region } \\
\text { of domicile }\end{array}$ & 0.193 & ed \\
\hline $\mathrm{H} 3$ & The level of DIS significantly differs among different demographic groups. & - & Supported \\
\hline $\mathrm{H} 4 \mathrm{a}$ & The 1 & 0.935 & pported \\
\hline $\mathrm{H} 4 \mathrm{~b}$ & gnificantly difference among ages. & 0.842 & Not supported \\
\hline$\overline{\mathrm{H} 4 \mathrm{c}}$ & The level of LCS is significantly difference among occupations. & 0.684 & Not supported \\
\hline $\mathrm{H} 4 \mathrm{~d}$ & The level of LCS is significantly difference among working experiences. & 0.613 & Not supported \\
\hline $\mathrm{H} 4 \mathrm{e}$ & The level of LCS is significantly difference among level of income. & 0.100 & Not supported \\
\hline $\mathrm{H} 4 \mathrm{f}$ & The level of LCS is significantly difference among education backgrounds. & 0.135 & Not supported \\
\hline $\mathrm{H} 4 \mathrm{~g}$ & $\begin{array}{l}\text { The level of LCS is significantly difference among different students' region } \\
\text { of domicile }\end{array}$ & 0.095 & Not supported \\
\hline $\mathrm{H} 4$ & The level of LCS significantly differs among different demographic groups. & - & Not supported \\
\hline
\end{tabular}

The results of a range of Anova analysis showed that an education background has a significant impact on digital and information skill (DIS). In other words, graduate students with a science background seem to have a higher level of digital and information skill set than a social science and business background. Additionally, in accordance to the result of Anova analysis, males also have a higher level of digital and information skill than females.

\section{DISCUSSION AND CONCLUSION}

The purposes of this study are to investigate the readiness of Thai peoples on Industry 4.0 and Thailand 4.0 policy, and examine any difference level of Thailand 4.0 essential skills among demographic groups. The results from the analysis also reveal that the lowest skill set for Thailand 4.0 is the digital and information skill $(\mathrm{M}=2.59)$ which can be interpreted as the poor level following by learning and innovation skill $(\mathrm{M}=3.03)$, and life and career skill $(M=3.66)$. Interestingly, life and career skill (LCS: $M=3.66)$ is ranked the highest readiness skill for Thai students in our study; nevertheless, once the authors consider into the sub skills of a life and career skill construct, we found that English skill readiness obtained for the samples is in the fair level comparing with other sub skills (adaptability, flexibility and collaborative skills, self-direction for the 
desirable value skills, and civic and global citizen) which are all in the good level. Hariharasudan and Kot (2018) stated that English is the medium of the digital world. English is not only considered as the language of communication but also the language of the Internet. The data from Internet World Stats (2017) cited in Hariharasudan and Kot (2018) represent that English language is ranked first among top ten languages on the Internet. The number of internet users by English language is 1,462,008,909 counting for $25.3 \%$ of total internet users in the world. The study results of Flammia and Saunders (2007) also showed that the most preferred language for digital literacy is English. English language is the most vital second language that people are required to accomplish Industry 4.0 concept in Thailand; however, an English language curriculum in Thailand fails to produce English competent students (Lohatepanont, 2017). According to the annual English Proficiency Index developed by EF Education First World Education Society in 2019, Thailand's ranking on the English Proficiency Index has dropped and the country now ranks 74th out of a total of 100 countries with a score of 47.62 considered a "Very low proficiency" in English language. Thailand has the third lowest score of Southeast Asian countries, behind Indonesia and ahead only of Myanmar and Cambodia, and ranks 17th out of 25 Asian countries (Sullivan, 2019).

The results also reveal that males have significantly higher level of digital and information skill than females. This finding is in the line with previous study by Tinmaz and Lee (2019) in Korean University students that males and females have significantly different level of industry 4.0 readiness in some certain areas. And, Science based education background samples have significantly higher level of digital and information skill than social science and business background. This finding is consistent with the concept of STEM (science, technology, engineering and mathematics) in education that can foster industry 4.0 readiness and it is very important to have high quality Industrial System within Industry 4.0 (Idin, 2018).

In order to achieve the Thailand 4.0 goals, digital and information skill seems to be the vital skill for Thai people that need to possess. However, our result showed that digital and information skill ranked lowest readiness compared to other skill. This dilemma challenges Thai government and need to rethink about strategies to overcome it. Reforming Thailand's education towards 4.0 is inevitable. Education reform must be expedited in order to access Thailand 4.0 substantially via the following actions (1) the development of English language skills (2) the promotion of the teaching and learning of mathematics and science (3) the development of analytical skill (4) the adjustment of the teaching and learning curriculum (5) the development and improvement of textbooks to meet global standards.

\section{LIMITATIONS AND RECOMMENDATIONS FOR FUTURE RESEARCHES}

This study has few limitations. Firstly, this study uses cross-sectional data, which relies on self-reported and perceptual measures and possibly lead to respondents' bias in the sample. The recall bias may have affected the data of this study. Future studies employing multiple methods such as experiment and other type of samples may help generalize the current outcomes of Industry 4.0 readiness and an essential skill situation. A longitudinal study is also recommended for providing more insights of Industry 4.0 
over time. Secondly, data collection was limited to the graduate student in Thailand newly industrialized country in Southeast Asia. Therefore, the findings should be circumspectly generalized for other newly industrialized countries and developing countries around the world. Comparative studies of Industry 4.0 readiness among different regions or stages of Economics development; namely factor driven, efficiency driven, and innovation driven economy, are recommended for gaining more insight and understanding with industry 4.0 challenges and opportunities.

\section{REFERENCES}

Agolla, J. E. (2018). Human Capital in the Smart Manufacturing and Industry 4.0 Revolution. In A. Petrillo, R. Cioffi, \& F. De Felice (Eds.), Digital transformation in smart manufacturing. InTech.

Bahrin, M. A. K., Othman, M. F., Azli, N. N., \& Talib, M. F. (2016). Industry 4.0: A review on industrial automation and robotic. Jurnal Teknologi, 78(6-13), 137-143.

Baldassarre, F., Ricciardi, F., \& Campo, R. (2017). The advent of industry 4.0 in manufacturing industry: Literature review and growth opportunities. Dubrovnik International Economic Meeting, 3(1), 632-643.

Bamrungsin, P. (2017). Enhancement students' innovation and learning skills for 21 st century and Thailand 4.0: A case study of Mahapajabati Buddhist College, Thailand. 5th International Scholars' Conference Proceedings. Bangkok, Thailand.

Bartodziej, C. J. (2017). The concept industry 4.0. In The Concept Industry 4.0 (pp. $27-$ 50). Springer Gabler, Wiesbaden.

Berawi, M. A. (2018). Utilizing big data in industry 4.0: Managing competitive advantages and business ethics. Int. J. Technol, 9, 430-433.

Hariharasudan, A., \& Kot, S. (2018). A scoping review on Digital English and Education 4.0 for Industry 4.0. Social Sciences, 7(11), 227.

Hartmann, E. A., \& Bovenschulte, M. (2013). Skills needs analysis for "Industry 4.0" based on roadmaps for smart systems. In Using Technology Foresights for Identifying Future Skills Needs. Global Workshop Proceedings (pp. 24-36).

Idin, S. (2018). An Overview of STEM Education and Industry 4.0. RESEARCH HIGHLIGHTS IN STEM EDUCATION, 194-208.

Jones, C., \& Pimdee, P. (2017). Innovative ideas: Thailand 4.0 and the fourth industrial revolution. Asian International Journal of Social Sciences, 17(1), 4-35.

Lohatepanont, K. (2017). Towards Thailand 4.0. Retrieved from https://kenlwrites.com/2017/01/08/towards-thailand-4-0/

Luanguepin, O. (2016), “Thailand 4.0, what do you need to know?", September 15, available at: www. thailand business-news.com/economics/54286-thailand-4-0-needknow.html (accessed July 20, 2017). 
Rojko, A. (2017). Industry 4.0 concept: background and overview. International Journal of Interactive Mobile Technologies (iJIM), 11(5), 77-90.

Rüßmann, M., Lorenz, M., Gerbert, P., Waldner, M., Justus, J., Engel, P., \& Harnisch, M. (2015). Industry 4.0: The future of productivity and growth in manufacturing industries. Boston Consulting Group, 9.

Shuhaimi, F. L., \& Awaludin, F. A. (2018). English communication for digital technology: Bridging the gap between Industrial Revolution 4.0 requirements and graduates readiness. Journal of Education and Social Sciences, 10(1), 144-150.

Sullivan, B. (2019). Thailand's English proficiency falls to "very low". Retrieved from https://www.thailand-business-news.com/news/76941-thailands-english-proficiency-

falls-to-very-low.html

Tantivorawong, V., Polsaram, P., \& Areesoponpichet, S. (2015). A Proposed Model of Corporate Governance Characteristics Development of Small and Medium Entrepreneur for Undergraduate Students Majoring Business Administration by Using Cognitive Apprenticeship in Social Network. Scholar, 7(1).

Thai Embassy-Washington, D.C. (2017). What is Thailand 4.0? Retrieved from http://thaiembdc.org/thailand-4-0-2/

Tinmaz, H., \& Lee, J. H. (2019). A Preliminary Analysis on Korean University Students' Readiness Level for Industry 4.0 Revolution. Participatory Educational Research, 6(1), 70-83.

Welsh, B. L. (2018). Education 4.0 - How We Will Learn in the Fourth Industrial Revolution. Retrieved from https://medium.com/@brianna_91610/education-4-0-howwe-will-learn-in-the-fourth-industrial-revolution-e17206b73016

Wipatayotin, A. (2017, March 18). Prayut touts 'Thailand 4.0' for farmers. Great chance to boost life quality, PM says. Bangkok Post. Retrieved from http://tinyurl.com/ldzkmvz

World Economic Forum. (2016, January). The future of jobs: Employment, skills and workforce strategy for the fourth industrial revolution. In Global Challenge Insight Report, World Economic Forum, Geneva.

\section{APPENDIX}

Appendix A

The concept of Thailand 4.0 classified the stages of economic development into 4 phrases. The summary of economic development is as the Table.

Table

The summary of Thai economic development

\begin{tabular}{lll}
\hline Stage & Description \\
\hline $\begin{array}{l}\text { Thailand } 1.0 \text { is about } \\
\text { agriculture. }\end{array}$ & $\begin{array}{l}\text { During this stage, Thais had made a living out of farmland and livestock. They } \\
\text { had grown rice and various other plants to support themselves. They had also }\end{array}$ \\
\hline
\end{tabular}


raised pigs, ducks and chicken to generate income.

Thailand 2.0 is about In this stage, Thais started using tools in their economic activities. The country

light industries. $\quad$ started manufacturing clothes, bags, beverages, stationery, ornaments, etc. On the overall, Thailand's potential had soared.

Thailand 3.0 (the today's At present, Thailand has manufactured and exported steel, automobiles, natural Thailand) is about heavy gases and more. The country, so far, has still relied on foreign technologies in industries. driving its exports

Thailand 4.0 is about Thailand 4.0 is an economic model that aims to unlock the country from innovation, technology, several economic challenges resulting from past economic development models and creativity driven which place emphasis on agriculture (Thailand 1.0), light industry (Thailand economy. 2.0), and advanced industry (Thailand 3.0). These challenges include "a middle Source: (Luanguepin, 2016) income trap", "an inequality trap", and "an imbalanced trap".

International Journal of Instruction, July $2020 \bullet$ Vol.13, No.3 